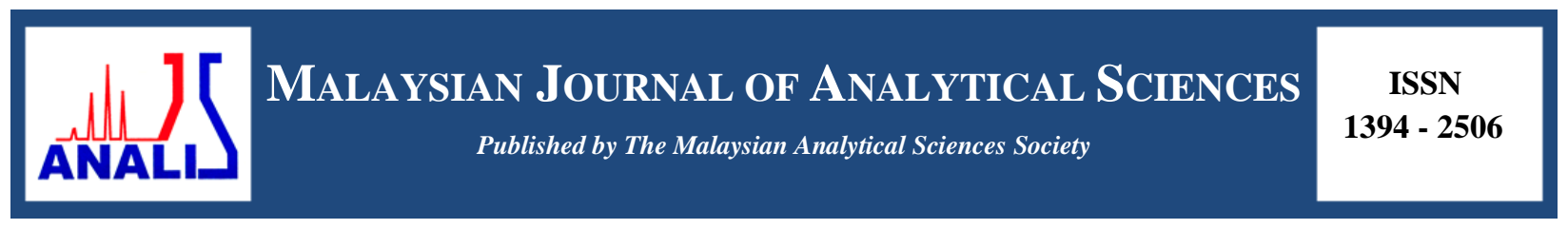

\title{
XYLOOLIGOSACCHARIDES PRODUCTION FROM OIL PALM FROND BY Trichoderma longibrachiatum XYLANASE
}

\author{
(Penghasilan Xilooligosakarida daripada Pelepah Kelapa Sawit Menggunakan Xilanase \\ Trichoderma longibrachiatum)
}

\author{
Sabiha Hanim Saleh ${ }^{1 *}$, Siti Normah Mohd Damanhuri Shah ${ }^{1}$, Khalilah Abdul Khalil ${ }^{2}$, Aishah Bujang ${ }^{3}$ \\ ${ }^{I}$ School of Chemistry and Environment \\ ${ }^{2}$ School of Biology \\ ${ }^{3}$ School of Food Science and Technology \\ Faculty of Applied Sciences, \\ Universiti Teknologi MARA, 40450 Shah Alam, Selangor Malaysia \\ *Corresponding author: sabihahanim@salam.uitm.edu.my
}

Received: 24 February 2015; Accepted: 27 October 2015

\begin{abstract}
Oil palm fronds containing rich hemicellulose are low cost resources that could be potentially converted into valuable products such as xylooligosaccharides. The main objective of this study was to investigate the production of xylooligosaccharides from OPF hemicelluloses using Trichoderma longibrachiatum xylanase. The OPF hemicellulose extracted by alkaline extraction was hydrolysed by xylanase at $\mathrm{pH} 4.6$, temperature $40{ }^{\circ} \mathrm{C}$, hemicellulose substrate concentration $2 \%(\mathrm{w} / \mathrm{v}$ ) and enzyme concentration $2 \mathrm{U} / \mathrm{ml}$ for different period of time from 0 to 48 hours to produce xylooligosaccharides. The hydrolysate obtained from enzymatic hydrolysis was further purified through ultrafiltration using $10 \mathrm{kDa}$ molecular weight cut off membranes. The highest total of xylobiose and xylotriose was found to be $21.91 \mathrm{mg} / \mathrm{mL}$ and obtained at 8 hours of hydrolysis time. After ultrafiltration step, xylooligosaccharides mixture were obtained in the permeate and retentate. The highest xylobiose $(56.64 \mathrm{~g} / 100 \mathrm{~g})$ and xylotriose $(45.80 \mathrm{~g} / 100 \mathrm{~g})$ were found in retentate and permeate, respectively.
\end{abstract}

Keywords: xylooligosaccharides, oil palm frond, ultrafiltration, enzymatic hydrolysis, xylanase

\section{Abstrak}

Pelepah kelapa sawit yang kaya dengan hemisellulosa adalah sumber kos rendah yang berpotensi untuk ditukarkan kepada produk bernilai seperti xilooligosakarida. Objektif utama kajian ini adalah untuk menyiasat penghasilan xilooligosakarida daripada hemisellulosa pelepah kelapa sawit menggunakan enzim xilanase Trichoderma longibrachiatum. Hemisellulosa yang diekstrak daripada pelepah kelapa sawit menggunakan alkali, dihidrolisis menggunakan enzim xilanase pada $\mathrm{pH} 4.6$, suhu $40{ }^{\circ} \mathrm{C}$, kepekatan hemiselulose $2 \%$ (w/v) dan kepekatan enzim 2U/ml umtuk tempoh masa berbeza dari 0 hingga 48 jam untuk menghasilkan xilooligosakarida. Hidrolisat yang diperoleh daripada hidrolisis enzimatik kemudiannya ditulenkan melalui ultrafiltrasi menggunakan membran yang berat molekulnya $10 \mathrm{kDa}$. Jumlah tertinggi xilobios dan xilotrios adalah $21.91 \mathrm{mg} / \mathrm{mL}$ yang diperoleh pada masa hidrolisis 8 jam. Setelah ultrafiltrasi, campuran xilooligosakarida diperoleh dalam 'permeate' dan 'retentate'. Kandungan tertinggi xilobios $(56.64 \mathrm{~g} / 100 \mathrm{~g})$ dan xilotrios $(45.80 \mathrm{~g} / 100 \mathrm{~g})$ ditemui di dalam 'retentate' dan 'permeate'.

Kata kunci: xilooligosakarida, pelepah kelapa sawit, ultrafiltrasi, hidrolisis enzimatik, xilanase 


\section{Introduction}

Oil palm fronds (OPF) generated the most of waste among the other biomass with 54.17 million tons and 54.24 million tons from oil palm industry in Malaysia for year 2010 and 2011, respectively [1]. The OPF is available daily throughout the year when the palms are pruned during the harvesting of bunches of fresh fruit. It is composed of hemicelluloses, cellulose and lignin. Hemicellulose extracted by alkaline extraction can be used as starting material for xylooligosaccharides (XOs) production. XOs are sugar oligomers made up of xylose unit. XOs can be used as ingredients of functional foods, cosmetics, pharmaceuticals or agricultural products [2]

Enzymatic method is more preferable to produce XOs compared to other methods, because it does not produce undesirable component or high amount of monomers and does not require special equipment [3]. Enzymatic production of xylooligosaccharides performed by xylanase having high endoxylanase and low $\beta$-xylosidase activity besides present of others side group enzyme removal include $\alpha$-arabinofuranosidases, acetylxylan esterase, and $\alpha$ glucuronidase [4]. Membrane separations, such as ultrafiltration and nanofiltration have been shown to be very promising methods for refining and concentrating several oligosaccharides [3]. Membrane technologies have been applied successfully in conjugation with enzymatic hydrolysis following steam hydrolysis for processing XOs.

Previous study used Trichoderme viride xylanase to produce XOs from OPF. However the result showed that the yield of XOs was only $25.64 \%$ [5]. Since there is also no purification step was performed in the previous study, thus in the present work, xylanase from Trichoderma longibrachiatum was used for enzymatic hydrolysis due to a few reports on their ability to produce high yield of XOs [6-8] following by ultrafiltration step. Therefore, the main objective of this study was to investigate the production of XOs mixture from alkaline extracted oil palm fronds hemicellulose using Trichoderma longibrachiatum and ultrafiltration.

\section{Raw material}

\section{Materials and Methods}

Oil palm frond (OPF) samples used in this study were obtained from local farmers in Perak, Malaysia. The samples were chipped, ground and sieved into fibers with width and length of $0.5 \mathrm{~mm}$ and 3 to $8 \mathrm{~mm}$, respectively, and then stored at room temperature prior to use. All chemicals used were of analytical grade unless otherwise stated.

\section{Hemicellulose extraction}

Hemicellulose extraction from OPF was conducted according to the method reported by Anis [9] with some modifications. An amount of $50 \mathrm{~g}$ sample of oil palm frond chips were soaked in $3 \mathrm{M}$ potassium hydroxide (KOH) with the solid to liquid ratio of $1: 10$, stirred at $40{ }^{\circ} \mathrm{C}$ and $400 \mathrm{rpm}$ with mechanical heat stirrer (HS-30D, WiseStir) for 4 hours. Then, the crude hemicellulose was filtered. The filtrate was acidified with $50 \%$ (v/v) acetic acid to $\mathrm{pH}$ $4.8 \pm 0.1$ and allowed to stand for 24 hours at $4{ }^{\circ} \mathrm{C}$. The extracts were centrifuged (Centrifuged 5702, Eppendorf) at $3500 \mathrm{rpm}$ for $15 \mathrm{~min}$ and filtered. The precipitate was washed with $50 \mathrm{~mL}$ of $95 \%(\mathrm{v} / \mathrm{v}$ ) ethanol to eliminate acid residue from the sample before dried in an oven (UFB 500, Memmert) at $40{ }^{\circ} \mathrm{C}$ for 4 hours. The supernatant was then added with four volumes of $95 \%$ ethanol and was kept for overnight. Hemicellulose in the form of pellet was obtained from precipitate after centrifuged, while the supernatant was discarded. Finally, the pellet was dried in the oven and used as a hemicellulose source.

\section{Enzymatic hydrolysis}

A volume of $1 \mathrm{~mL}$ of $2 \mathrm{U} / \mathrm{mL}$ of xylanase from T. longibrachiatum (Sigma, USA) was added to $10 \mathrm{~mL}$ of $2 \%(\mathrm{w} / \mathrm{v}$ ) alkaline extracted hemicellulose solution from OPF in $0.05 \mathrm{M}$ citrate buffer at $\mathrm{pH}$ 4.6. The mixture was incubated at $40{ }^{\circ} \mathrm{C}$ with mild shaking in an incubator shaker (IKA ${ }^{\circledR} \mathrm{KS} 4000$ i Control, China). Enzymatic hydrolysis was carried out at $\mathrm{pH} 4.6$, temperature $40^{\circ} \mathrm{C}$, hemicellulose concentration $2 \%(\mathrm{w} / \mathrm{v})$ and enzyme concentration $2 \mathrm{U} / \mathrm{ml}$. This hydrolysis was conducted from 0 to 48 hours. Periodically, samples were taken out and the enzymatic reaction was stopped by boiling for $5 \mathrm{~min}$ before the samples were subjected to analyses. The hydrolysate obtained at optimal time was further used for purification step using ultrafiltration [10]. XOs contents were determined using HPLC.

\section{Purification of hydrolysate using Ultrafiltration}

Purification process was carried out using an Amicon Stirred Ultrafiltration Cell, Model 8400 (Millipore-Amicon, Bedford, MA) pressurized by nitrogen gas. A volume of $50 \mathrm{~mL}$ of hydrolysate obtained from hemicellulose 
hydrolysis was passed through the ultrafiltration system with $10 \mathrm{kDa}$ molecular weight cut off (MWCO) membrane. The operating condition allowed membrane operating pressure $55 \mathrm{psi}$ at room temperature. The filtration was stopped when approximately $40 \mathrm{~mL}$ of permeate was collected. The total sugar in retentate and permeate after ultrafiltration process was determined by phenol/sulfuric acid method. The XOs content was determined by HPLC.

\section{Total sugar analysis}

Total sugar content in hydrolysate was measured by using the phenol-sulfuric acid method [11]. An amount of $1 \mathrm{~mL}$ of $5 \%(\mathrm{w} / \mathrm{v})$ phenol solution and $5 \mathrm{~mL}$ of $98 \%$ concentrated sulfuric acid were added to $1 \mathrm{~mL}$ of hydrolysate. The mixture was mixed well and kept at room temperature for 10 minutes for color development before being cooled in the water bath (Memmert, Germany) at $25{ }^{\circ} \mathrm{C}$ for 20 minutes. The absorbance was measured at wavelength $480 \mathrm{~nm}$ by UV spectrophotometer (Perkin Elmer Precise, 35 Lambda, USA). The amount of total sugar was expressed as $\mathrm{mg} / \mathrm{mL}$ alkaline extracted hemicellulose (pellet).

\section{Monosaccharides determination by HPLC}

The content of monosaccharides in the XOs-containing liquor from ultrafiltration process was determined by HPLC (Agilent Technologies 1200 Series, Germany) using Aminex HPX 87P column (300 mm x $7.8 \mathrm{~mm}$ ). The HPLC was equipped with a refractive index detector (G 1362A, Agilent Technologies 1200 Series, Germany) and column oven (Agilent Technologies 1200 Series, Germany). The sample was filtered through a $0.20 \mu \mathrm{m}$ nylon syringe filter (Minisart, Sartorius AG, Germany) prior to direct injection into HPLC. The sample was eluted using deionised water as the mobile phase at column temperature of $80^{\circ} \mathrm{C}$ and a flow rate of $0.5 \mathrm{~mL} / \mathrm{min}$.

\section{Xylooligosaccharides determination by HPLC}

XOs were analyzed by HPLC (Agilent Technologies 1200 Series, Germany) equipped with a refractive index detector (G 1362A, Agilent Technologies 1200 Series, Germany), and column oven (Agilent Technologies 1200 Series, Germany). A volume of $2 \mathrm{~mL}$ of hydrolysate obtaining from ultrafiltration was filtered through a $0.20 \mu \mathrm{m}$ nylon syringe filter (Minisart, Sartorius AG, Germany). A $20 \mu \mathrm{L}$ volume of the filtered sample was injected into HPLC. The sample was eluted using deionised water as the mobile phase. The BioRad-Aminex HPX 42A column $\left(300 \mathrm{~mm} \times 7.8 \mathrm{~mm}\right.$ ) was used at $80{ }^{\circ} \mathrm{C}$ and a flow rate of $0.5 \mathrm{~mL} / \mathrm{min}$. Concentration of XOs was measured using an average peak areas compared to the mixture of XOs standards and expressed as $\mathrm{mg} / \mathrm{mL}$ XOs. Standard calibration curve was plotted based on peak areas against concentration of XOs standards.

\section{Monosaccharides Composition of Hemicellulose}

\section{Results and Discussion}

The monosaccharide compositions of OPF hemicellulose were xylose, arabinose and glucose. Xylose was the major component with $46.67 \%(\mathrm{w} / \mathrm{w})$ found in the OPF hemicellulose indicating the existence of xylan as the main polysaccharides [12], followed by a small amount of arabinose and glucose with $11.01 \%(\mathrm{w} / \mathrm{w})$ and $9.01 \%(\mathrm{w} / \mathrm{w})$, respectively. Xylose probably originated from the backbone of the hemicellulose [13], while arabinose and glucose came from the side chain [14]. This result is in accordance with the finding reported by Fazilah et al. [15] using similar raw materials.

\section{Enzymatic hydrolysis of OPF}

Table 1 shows the enzymatic hydrolysis of OPF for a period of time from 0 to 48 hours using $2 \mathrm{U} / \mathrm{mL}$ xylanase concentrations with $2 \%$ (w/v) OPF hemicellulose substrate at $\mathrm{pH} 4.6$ and $40{ }^{\circ} \mathrm{C}$. HPLC analysis indicated that OPF hemicellulose is hydrolysed to xylose and a variety of XOs fractions, which are xylobiose, xylotriose, xylotetraose, xylopentaose and xylohexaose.

During the initial 2 hours, the concentration of xylobiose decreased as much as to $42 \%$ from $7.24 \pm 0.44 \mathrm{mg} / \mathrm{mL}$ to $4.19 \pm 0.06 \mathrm{mg} / \mathrm{mL}$, and the concentration of xylotriose decreased slightly from $8.93 \pm 0.16 \mathrm{mg} / \mathrm{mL}$ to $8.32 \pm 0.47$ $\mathrm{mg} / \mathrm{mL}$, which corresponds to $7 \%$. However, the concentration of xylobiose and xylotriose increased rapidly at 8 hours. The highest total of xylobiose and xylotriose was $21.91 \mathrm{mg} / \mathrm{mL}$ at hydrolysis time of 8 hours. Further increase in the time from 8 to 24 hours significantly decrease $(p<0.05)$ the xylobiose and xylotriose concentrations. 
In the present study, XOs in the range of xylobiose to xylohexaose except xylotetraose were produced by Trichoderma longibrachiatum xylanase in all hydrolysis time. This result was in accordance with the study reported by Akpinar et al. [3] for the production of XOs from cotton stalk using Aspergillus niger xylanase. The absence of xylotetraose in all hydrolysis time was due to its immediate hydrolysis into smaller oligosaccharides once it was produced. The concentration of xylopentaose increased from 0 to 2 hours, whereas the concentration of xylohexaose increased from 0 to 8 hours. Further increase the hydrolysis time from 8 to 24 hours did not significantly increase the xylopentaose and xylohexaose.

Table 1. Concentration of Xylose and XOs at different time of hydrolysis

\begin{tabular}{lccccc}
\hline \multirow{2}{*}{$\begin{array}{l}\text { Sugars } \\
(\mathbf{m g} / \mathbf{m L})\end{array}$} & \multicolumn{5}{c}{ Hydrolysis Time (hour) } \\
\cline { 2 - 6 } & $\mathbf{0}$ & $\mathbf{2}$ & $\mathbf{8}$ & $\mathbf{2 4}$ & $\mathbf{4 8}$ \\
\hline Xylose & $0.04 \pm 0.01^{\mathrm{a}}$ & $1.74 \pm 0.05^{\mathrm{b}}$ & $8.46 \pm 0.32^{\mathrm{c}}$ & $17.78 \pm 0.90^{\mathrm{d}}$ & $23.79 \pm 0.33^{\mathrm{e}}$ \\
Xylobiose & $7.24 \pm 0.44^{\mathrm{c}}$ & $4.19 \pm 0.06^{\mathrm{b}}$ & $9.70 \pm 0.04^{\mathrm{d}}$ & $3.25 \pm 0.59^{\mathrm{a}}$ & $3.77 \pm 0.42^{\mathrm{b}}$ \\
Xylotriose & $8.93 \pm 0.16^{\mathrm{c}}$ & $8.32 \pm 0.47^{\mathrm{bc}}$ & $12.21 \pm 0.59^{\mathrm{d}}$ & $0.86 \pm 0.67^{\mathrm{a}}$ & $7.19 \pm 1.12^{\mathrm{b}}$ \\
Xylotetraose & n.d & n.d & n.d & n.d & n.d \\
Xylopentaose & $3.69 \pm 0.13^{\mathrm{a}}$ & $9.31 \pm 0.11^{\mathrm{c}}$ & $6.45 \pm 0.51^{\mathrm{b}}$ & $5.98 \pm 0.25^{\mathrm{b}}$ & $5.96 \pm 0.11^{\mathrm{b}}$ \\
$\begin{array}{l}\text { Xylohexaose } \\
\text { Xylobiose }\end{array}$ & $3.85 \pm 0.03^{\mathrm{a}}$ & $3.02 \pm 0.45^{\mathrm{a}}$ & $7.05 \pm 0.09^{\mathrm{b}}$ & $7.18 \pm 0.49^{\mathrm{b}}$ & $6.90 \pm 0.15^{\mathrm{b}}$ \\
$\begin{array}{l}\text { Xylotriose } \\
\text { (Total) }\end{array}$ & 16.17 & 12.51 & 21.91 & & \\
\hline
\end{tabular}

Results are presented as means \pm standard deviation $(n=3)$, Mean values followed by different superscript letters in a row are significantly different $(p<0.05)$, n.d: not detected.

Table 1 also shows that extending the reaction time to 48 hours did not significantly increase the production of XOs, but instead produced high amount of xylose. The amount of xylose increased drastically after 2 hours. These results were corroborated with the yield of the XOs, which decreased after 8 hours due to a small amount of XOs was hydrolysed into monosaccharides, thus could also inhibit the production of XOs [16]. The concentration of xylose also increased drastically when the reaction time increased. The concentration of Xylose rose up to $23.79 \mathrm{mg} / \mathrm{mL}$ when hydrolysis time increased to 48 hours. The result showed that increasing hydrolysis time resulted in higher xylose production.

\section{Purification of OPF XOs by Ultrafiltration}

It can be seen that the composition of permeate with molecular weight of $10 \mathrm{kDa}$ MWCO membrane exhibited higher content of xylotriose, followed by xylopentaose, xylohexaose and xylobiose (Table 2). The xylobiose composition in the initial feed decreased from $27.40 \mathrm{~g} / 100 \mathrm{~g}$ to $10.64 \mathrm{~g} / 100 \mathrm{~g}$, whereas xylotriose composition increased from $34.47 \mathrm{~g} / 100 \mathrm{~g}$ to $45.80 \mathrm{~g} / 100 \mathrm{~g}$ when passing through $10 \mathrm{kDa}$ MWCO membrane. It was found that xylobiose was decreased by $61 \%$, while xylotriose was increased by $33 \%$ in the permeate. In addition, xylopentaose and xylohexaose composition in the permeate increased slightly from initial feed with $22 \%$ and $7 \%$, respectively.

Both xylopentaose and xylohexaose composition decrease in the retentate by $33 \%$ and $38 \%$, respectively. Other than that, xylobiose composition in the retentate increased significantly $(p<0.05)$ from $27.40 \mathrm{~g} / 100 \mathrm{~g}$ to 56.64 $\mathrm{g} / 100 \mathrm{~g}$. This result showed that the composition of xylobiose in the retentate was higher compared to in permeate. However, xylotriose decrease significantly $(p<0.05)$ from $34.47 \mathrm{~g} / 100 \mathrm{~g}$ to $18.73 \mathrm{~g} / 100 \mathrm{~g}$ in the retentate. The initial feed containing XOs was fractionated with $10 \mathrm{kDa}$ MWCO membrane, clearly showed that the permeate 
fraction containing XOs ranging from xylobiose to xylohexaose. In contrast, the retentate fraction containing XOs is ranging from xylobiose to xylohexaose. However, Akpinar et al. [3] found that ultrafiltration with $10 \mathrm{kDa}$ MWCO membrane successfully retained mainly high molecular weight oligosaccharides in the retentate. The presence of low molecular weight oligosaccharides in retentate may be due to fouling mechanism. Fouling mechanism caused by blocking of pore in high cut-off membrane by big molecules, so that transportation of small molecules was hindered. Membrane selection is also very important in order to reduce fouling problem [17].

Table 2. Total sugar concentration and composition of permeate and retentate at 8 hours of hydrolysis.

\begin{tabular}{lcccc}
\hline XOs & $\begin{array}{c}\text { Initial feed } \\
\text { amount } \\
(\text { Total sugar, } \\
\mathbf{m g} / \mathbf{m l})\end{array}$ & $\begin{array}{c}\text { Composition } \\
\text { of feed } \\
(\mathbf{g} / \mathbf{1 0 0 g})\end{array}$ & $\begin{array}{c}\text { Composition of permeate } \\
\text { of MWCO 10 kDa } \\
\text { membrane } \\
(\mathbf{g} / \mathbf{1 0 0 g})\end{array}$ & $\begin{array}{c}\text { Composition of retentate } \\
\text { of MWCO 10 kDa } \\
\text { membrane } \\
(\mathbf{g} / \mathbf{1 0 0 g})\end{array}$ \\
\hline Total & 35.42 & 100.00 & 100.00 & 100.00 \\
Xylobiose & $9.70 \pm 0.04$ & $27.40^{\mathrm{b}}$ & $10.64^{\mathrm{a}}$ & $56.64^{\mathrm{c}}$ \\
Xylotriose & $12.21 \pm 0.59$ & $34.47^{\mathrm{b}}$ & $45.80^{\mathrm{c}}$ & $18.73^{\mathrm{a}}$ \\
Xylotetraose & 0.00 & 0.00 & 0.00 & 0.00 \\
Xylopentaose & $6.45 \pm 0.51$ & $18.22^{\mathrm{b}}$ & $22.23^{\mathrm{c}}$ & $12.25^{\mathrm{a}}$ \\
Xylohexaose & $7.05 \pm 0.09$ & $19.92^{\mathrm{b}}$ & $21.33^{\mathrm{c}}$ & $12.38^{\mathrm{a}}$ \\
\hline
\end{tabular}

Mean \pm standard deviation of at least duplicate determinations. Mean values followed by different superscript letters in a row are significantly different $(p<0.05)$.

\section{Conclusion}

The highest total of xylobiose and xylotriose was found to be $21.91 \mathrm{mg} / \mathrm{mL}$ and obtained at 8 hours of hydrolysis time. After ultrafiltration step, mostly xylooligosaccharides mixture were obtained in the permeate and retentate. The highest xylobiose $(56.64 \mathrm{~g} / 100 \mathrm{~g})$ and xylotriose $(45.80 \mathrm{~g} / 100 \mathrm{~g})$ were found in retentate and permeate respectively.

\section{Acknowledgement}

The authors are grateful to the Ministry of Education Malaysia, Research Management Institute (RMI), Universiti Teknologi MARA for the financial support under the Exploratory Research Grant Scheme (ERGS):600-RMI/ERGS 5/3 (8/2012) and Faculty of Pharmacy, UiTM Puncak Alam for using HPLC equipment.

\section{References}

1. Ofori-Boateng, C. and Lee, K.T. (2013). Response surface optimization of ultrasonic-assisted extraction of carotenoids from oil palm (Elaeis guineensis Jacq.) fronds. Food Science and Nutrition, 1 (3): 209 - 221.

2. Vázquez, M. J., Alonso, J. L., Domínguez, H. and Parajó, P. C. (2000). Xylooligosaccharides: manufacture and application. Trends in Food Science and Technology, 11:387 - 393.

3. Akpinar, O., Ak, O., Kavas, A., Bakir, U. and Yilmaz, L. (2007). Enzymatic production of xylooligosaccharides from cotton stalks. Journal of Agricultural and Food Chemistry, 55: 5544 - 5551.

4. Carvalho, A. F. A., Neto, P. O., Silva, D. F. and Pastore, G. M. (2013). Xylooligosaccharides from lignocellulosic materials: Chemical structure, health benefits and production by chemical and enzymatic hydrolysis. Food Research International, 51: 75 - 85. 
5. Sabiha-Hanim, S., Nor, M. A. M. and Rosma, A. (2011). Effect of autohydrolysis and enzymatic treatment on oil palm (Elaeis guineensis Jacq.) frond fibres for xylose and xylooligosaccharides production. Bioresource Technology, 102: $1234-1239$.

6. Royer, J. C. and Nakas, J. P. (1991). Purification and characterization of two xylanases from Trichoderma longibrachiatum. European Journal of Biochemistry, 202: 521 - 529.

7. Chen, C. S., Chen, J. L. and Lin, T. Y. (1997). Purification and characterization of a xylanase from Trichoderma longibrachiatum for xylooligosaccharide production. Enzyme and Microbial Technology, 21: 91 96.

8. Akpinar, O. and Bostanci, S. (2009). Xylooligosaccharide production from lignocellulosic wastes with Trichoderma longibrachiatum xylanase. Journal of Food, Agriculture \& Environment, 7 (1): 70 - 74.

9. Anis. M. (2000). Extraction and functional properties of oil palm biomass. Doctoral dissertation, Universiti Sains Malaysia, Penang, Malaysia

10. Akpinar, O., Erdogan, K. and Bostanci, S. (2009). Enzymatic production of xylooligosaccharides from selected agricultural wastes. Food and Bioproducts Processing, 87: $145-151$

11. Dubois, M., Gillies, K. A., Hamilton, J. K., Rebers, P. A. and Smith, F. (1956). Colorimetric method for determination of sugars and related substances. Analytical Chemistry, 28(3): $350-357$.

12. Ruiz, H. A., Cerquira, M. A., Silva, H. D., Rodríguez-Jasso, R. M., Vicente, A. A. and Teixeira, J. A. (2013). Biorefinery volarization of autohydrolysis wheat straw hemicellulose to be applied in a polymer-blend film. Carbohydrate Polymers, 92: 2154 - 2162.

13. Luo, Q., Peng, H., Zhou, M., Lin, D., Ruan, R., \& Wan, Y., Zhang, J. and Liu Y. (2012). Alkali extraction and physicochemical characterization of hemicelluloses from young bamboo (Phyllostachys pubescens mazel). Bioresources, 7(4): $5817-5828$.

14. Bian, J., Peng, F., Peng, P., Xu, F. and Sun, R-C. (2010). Isolation and fractionation of hemicelluloses by graded ethanol precipitation from Caragana korshinskii. Carbohydrate Research, 345: 802 - 809.

15. Fazilah, A., Azemi, M. N. M., Karim, A. A., and Norakma, M. N. (2009). Physicochemical properties of hydrothermally treated hemicellulose from oil palm frond. Journal of Agricultural and Food Chemistry, 57: $1527-1531$.

16. Akpinar, O., Gunay, K., Yilmaz, Y., levent, O. and Bostanci, S. (2010). Enzymatic process and antioxidant activity of agricultural waste autohydrolysis liquors. Bioresources, 5(2): $699-711$.

17. Gullón, P., González-Muñoz, M. J., Domínguez, H. and Parajó, J. C. (2008). Membrane processing of liquors from Eucalyptus globulus autohydrolysis. Journal of Food Engineering, 87: 257 - 265. 